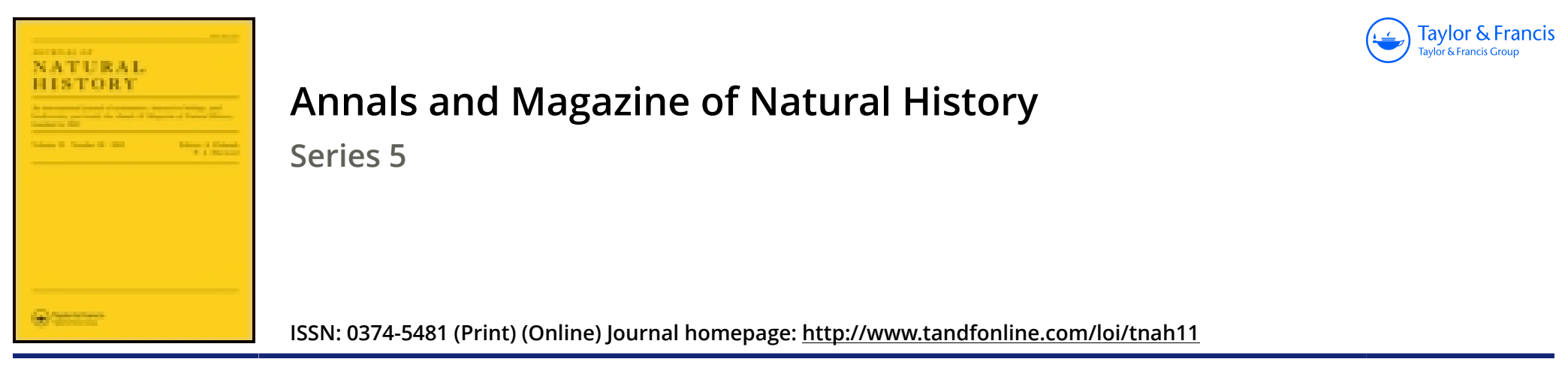

\title{
Histology, development, and origin of the testis and ovary in Campanularia angulata (Hincks)
}

\section{M.J. Fraipont}

To cite this article: M.J. Fraipont (1880) Histology, development, and origin of the testis and ovary in Campanularia angulata (Hincks), Annals and Magazine of Natural History, 5:27, 265-267, DOI: $10.1080 / 00222938009459423$

To link to this article: http://dx.doi.org/10.1080/00222938009459423

$$
\text { Published online: } 07 \text { Oct } 2009 .
$$

\section{Submit your article to this journal $\square$}

Џ Article views: 3 
occupied, the author suggests Gegeneophis for the genus in the event of its proving to be well founded. Urceotyphlus has the tentacular pit circular and the base of the cultrate tentacle at the bottom of the tentacular tube. It includes two East-Indian speciesCacilia oxyura, Dum. \& Bibr., and C. malabarica, Beddome. The genus Cocilia, as restricted, includes seven American speciesnamely, C. tentaculata, Linn., isthmica, Cope, gracilis, Shaw, pachynema, Günth., ochrocephala, Cope, polyzona, Fisch. (sp. n.), and Güntheri, sp. n. (=C. rostrata, Günth. non Cuv.). Hypogeophis has the eye visible; the species referred to it are Cacilia rostrata, Cuv., from the Seychelles, and C. Seraphini, Dum., from Gaboon and the Camaroons. Dermophis includes scaled species, which have been referred by previous authors to Wagler's genus Siphonops, founded upon the scaleless Cacitia annulata, Mikan. Prof. Peters refers to Dermophis the American species Siphonops mexicanus, Dum. \& Bibr., S. brasiliensis, Lütken, S. proximus, Cope, and S. simus, Cope, and the WestAfrican S. brevirostris, Pet., and S. thomensis, Bocage. Gymnopis closely approaches Siphonops in the structure of the skull. To this genus three American species are referred-namely, G. multiplicata, Pet., Rhinatrema unicolor, Dum., and Siphonops oligozona, Cope. Herpele, which approaches Coccilia in cranial structure, includes only one species, the West-African Ccecilia squalostoma, Stutchbury. In Chthonerpeton the tentacular pit is placed midway between eje and nostril, but considerably below the line joining those organs; the only known species is Siphonops indistinctus, Reinh. \& Lütk., from South America. The sole representative of the restricted genus Siphonops is Wagler's type species $C$. annulata, Mikan, from Brazil, Guiana, and Peru. Lastly, in Typhlonectes the eyes are distinct, and the anal aperture surrounded by a sort of sucking-disk. The species are all from South America-namely, Coceilia compressicauda, Dum. \& Bibr., C. dorsalis, Pet., C. natans, Fisch., and ? Siphonops syntremus, Cope. The foetal form has vesicular branchiæ. Prof. Peters's paper is illustrated with a plate elucidating the characters of the genera.-Monatsb. Akad. Wiss. Berl., November 1879, p. 924 .

Histology, Development, and Origin of the Testis and Ovary in Campanularia angulata (Hincks). By M. J. Fratpont.

The histological study of the three layers, ectoderm, intermediate lamella, and entoderm, of the body in Hydroids, leads to some new and important facts, of which a summary is here given.

The small nematocysts of the ectoderm of the tentacles are surrounded by a slight protoplasmic layer, often nucleolated and individualized, to which a palpocil corresponds. This relation is important from the physiological point of view, and that of the mode of action of the urticant organs.

The endoderm of the stolons in the vicinity of the pedicles of female gonangia (Campanularire angulata), and espocially in the branches (C. flexuos $\alpha$ ), contains larger cells, haring, on the one hand, 
the characters of egg-cells, and passing, on the other, into the endodermic cells. Our master, E. van Beneden, has long since made analogous observations (in Campanularia dichotoma), which are still unpublished.

The free extremity of the appendicular organ terminated in a hook is characterized by the development of the ectoderm, by the accumulation in that tissue of corpuscles of special structure, and by the considerable attenuation of the perisarc. These data may perhaps serve to settle the nature of this organ.

In the body and tentacles the intermediate lamella, which elsewhere is amorphous, presents fasciculated fibrils, which insert themselves at definite points, and which I believe to be muscular.

A gonangium is formed by a gonotheca, a central system of canals, and some gonophores. The axial canal or blastostyle spreads out into a hammer-head at the upper extremity of the yonangium, and furnishes laterally those cæca at the level of which the gonophores are formed. In $C$. angulata and $C$. flexuosa the latter do not become either Medusæ or semi-Medusæ, as in the other Campanularice; they remain in the condition of diverticula of the wall of the body, and certain of their cellular elements become ovary or testis.

The spermatozoids seem to be formed by a small nucleus, or fragment of a small nucleus, surrounded by a little of the protoplasm of the mother cell, of which the rest serves to form the tail.

The female gonophore contains only one ovum, the germinal vesicle of which, when not feeundated, is analogous to that described by W. Flemming, E. van Beneden, Kleinenberg, U. Hertwig, and Bergh in various animals. It contains a small clear corpuscle of irregular form (Schrön's corpuscle), from which start from three to six filaments which appear to terminate at the inner surface of the germinal spot; carmine colours it strongly. Segmentation by transverse furrows of unilateral direction produces a ciliated planula sbowing a cellular ectoderm and an endoderm.

Four opinions are current as to the origin of the sexual organs: Huxley, Keferstein and Ehlers, Claus, Kleinenberg, Schulze, O. and $R$. Hertwig think that the sexual organs originate from the ectoderm. On the other hand, Kölliker, Häckel, Allman, Claus, and Korotneff maintain their endodermic origin. F. van Beneden supports a third opinion, namely the ectodermic origin of the spermatozoids and the endodermic origin of the ova. Van Koch and Bergh confirmed Van Beneden's vicws. Lastly, Ciamician has maintained the ectodermic origin of the ova and the endodermic origin of the spermatozoids in Eudendrium ramosum.

In Campanularia angulata and C. flexuosa the whole development of the soxual organs may be traced by studying a gonangium from its base of insertion to its apex.

In the pedicle of the male gonangium, the ccenosarc is constituted as in the stolons and the branches; but at one or two points the ectoderm is more thickened and its cells better defined. Higher up, at a certain point, the conosarc is inflated into a small tubercle, into the interior of which penetrates a cacal diverticulum of the 
central cavity, bounded by a few endodermic cells. Beyond the latter we see the intermediate lamella, then some well individualized ectodermic cells, larger than the others (these are the mother cells of the testis); and finally the whole is covered by the ordinary ectodermic cells. In the cavity of the gonangium, at its base, are young gonophores, in which we find, from within outwards, a diverticulum of the cavity of the blastostyle, epithelial endodermic cells, the intermediate lamella, a small cellular mass of a horseshoe shape, originating from a few differentiated ectodermic cells, and, lastly, a layer of ectodermic cells. The little mass is the young testicular tissue. The different gonophores have the same constitution, with the exception of the development of the tissue, which gradually acquires a larger and larger volume. In the uppermost gonophores all the elements which surround the mature testis are in process of atrophy. The conclusion is that the spermatozoids originate from the ectoderm.

In the pedicle of a female gonangium we find at the base one or two large endodermic cells projecting into the gastrovascular cavity, having a large nucleus and no vibratile flagellum, in fact presenting all the characters of young ova of the gonophores. At the upper extremity of the pedicle we see one or two differentiated endodermic cells, but with no direct connexion with the gastrovascular cavity, as two or three small endodermic cells cover them. Further up, towards the base of the cavity of the gonangium, the cœnosare gives origin to lateral diverticula. One of them presents in its interior a small cavity, the carity of the cæcum of the blastostyle, bounded by a series of endodermic cells. To the cuter surface of this layer is attached a young ovum. The intermediate lamella passes above this ovum; and further ont is the ectodermic lamella. In the upper gonophores the same conditions exist, but the ova become more and more voluminous. When the ovum is mature the tissues surrounding it are in process of atrophy. The endodermic origin of the ova is therefore evident.

Bringing together these observations and those of $\mathbf{E}$. van Beneden and Bergh, I conclude that in the family Campanularidse the spermatozoids are developed at the cost of the extoderm, and the ova at the expense of the endoderm.-Comptes Rendus, Jan. 5, 1880, p. 43.

\section{On the Plants which serve as the Basis of various Curares. By M. G. Planchon.}

From the data now acquired it may be regarded as established that the plants which serve as the basis of the curare poison all belong to the genus Strychnos. The species of other families which enter into its composition only play a secondary part.

We know of four distinct regions which are centres of the preparation of curare; and for each of them we may indicate a principal plant which of itself explains the effects of the poison. These are, in the order of the dates at which they became known:-

1. British Guiana, furnishing the curare of the Macusis Indians. 